\title{
The Spirit of Black Lake: Full Employment, Civil Rights, and the Forgotten Early History of Environmental Justice
}

\author{
Josiah Rector
}

During the 1970s, activists first popularized the concept of "environmental justice" in the context of growing environmental degradation, racialized urban poverty, and working-class fears of plant closure. To address these problems, leaders in the United Auto Workers and other unions formed coalitions with civil rights and environmental groups, and advocated federal policies that would reduce both pollution and unemployment. This article argues that the defeat of these efforts, and the political marginalization of full employment and other social-democratic goals in the 1980s, resulted in a narrower conception of environmental justice among many scholars and activists. Revisiting this forgotten history calls into question common claims about environmentalism in recent scholarship on the 1970s, and suggests the need to revise conventional narratives of the emergence of the environmental justice movement.

On May 2, 1976, Lillian Benbow, Director of the Housing Program at the Michigan Civil Rights Commission, delivered a speech at the United Auto Workers's "Working for Environmental and Economic Justice and Jobs" conference at Black Lake, Michigan. Benbow said she was "happy to come and see some people who are concerned about the environment and working on it, concerned about jobs, and urban ills." However, unemployment in Detroit had increased from 11.5 percent in 1973 to 23.6 percent in 1975 . Social distress was mounting, especially among African Americans. Meanwhile, amidst a national energy crisis, auto manufacturers publicly blamed environmental regulations for job losses. In this context, Benbow questioned whether existing environmental policies helped African Americans. "Is the lack of a job any more devastating," she asked, "because it is eliminated by ecological guidelines than because of racism?" Turning to housing, she asked, "is planned land use any more restrictive because of environmental standards than exclusionary zoning designed to prevent minorities from living in suburbia?" Benbow recognized that, on average, African Americans in Detroit suffered more from pollution than whites in the suburbs. But unless environmental policies addressed racial discrimination, urban poverty, and unemployment, they would reinforce inequality. ${ }^{1}$

During a panel on "The Environment and the Poor," William B. Ratliff of the Greenville, South Carolina Urban League made a similar plea for environmentalism to be linked to a full employment and civil rights agenda. "The basic causes of environmental and economic injustice," he argued, were "discrimination, over-concentration of wealth, and a shortage of

I would like to thank Sarah Phillips, Brooke Blower, and the rest of the MAH staff for their feedback and editorial assistance. For comments on earlier drafts, I would also like to thank my anonymous reviewers, as well as Emily MacGillivray, Jessica Eckhardt, Travis Proctor, and Kyle Bladow.

${ }^{1}$ Lilian Benbow, Michigan Civil Rights Commission, speech transcript, proceedings, "Working for Environmental and Economic Justice and Jobs" conference, Black Lake, Michigan, May 2, 1976, 1-4, folder 12, box 10, United Auto Workers Conversation and Recreation Department Collection (hereafter UAW-CRD), Walter P. Reuther Archive of Labor and Urban Affairs, Detroit, MI.

(c) The Author(s) 2018. Published by Cambridge University Press 
economic democracy." In order to "overcome these conditions," he said, environmentalists, community activists, and workers needed to support "the economic goals of full employment, income maintenance, and a more equitable redistribution of wealth." Other conference participants echoed these sentiments. Many, including the Black Caucus and the Women's Caucus, endorsed the Humphrey-Hawkins Full Employment bill, which promised to lower unemployment to 3 percent for persons over the age twenty in four years. Full employment, they argued, would make it unnecessary for workers to choose between jobs and protection from pollution. These ideas built on the social-democratic approach to environmental problems articulated in the A. Philip Randolph Institute's Freedom Budget for All Americans (1967). ${ }^{2}$

The Black Lake conference emerged from a series of coalition-building efforts among labor, environmental, and civil rights activists in the 1970s. Yet many influential interpretations of the decade have ignored these efforts, repeating a "post-material" interpretation of environmentalism inherited from older social science literature on "new social movements." For example, Judith Stein portrays 1970s environmentalism as a cause of affluent, suburban New Democrats who believed that "posteconomic issues" such as "race, gender, foreign policy, and the environment were the important ones." Lily Geismer, while incisively critiquing Stein's claim that these issues were "posteconomic," also associates environmentalism with New Democrats who catered to the "materialist concerns of suburban knowledge workers rather than autoworkers." Michael Stewart Foley yokes environmentalism in the 1970s and 1980s to a "culture of self-reliance" among activists angered by the government's failure to protect their homes and communities from toxic waste, plant closures, AIDS, and other threats. Jefferson Cowie, drawing on Foley's work, suggests that environmentalism was a "front porch politics" that won "cleaner air and water" but did little to challenge inequality or boost working-class incomes. ${ }^{3}$

Although these characterizations apply to some segments of 1970s environmentalism, they fail to explain others, including the coalition politics that produced the environmental justice movement. Both rank-and-file auto workers and UAW leaders in this era understood that reducing industrial pollution served the material interests of working-class people, particularly people of color segregated in the most toxic occupations and neighborhoods. Moreover, rather than advocating "self-reliance" or spurning redistribution, many of the participants at Black Lake wanted to expand the regulatory state, welfare programs, and the power of unions. Indeed, the concepts of "environmental justice" and "environmental racism" first entered social movement discourse in the context of such coalition efforts. Narratives of the environmental justice movement, written by academics as well as activists, too frequently omit this history. Most begin the story in 1982, with the mass protests against polychlorinated biphenyl (PCB) dumping in Warren County, North Carolina. Others choose earlier precedents, such as the 1979 Bean v. Southwestern Waste Management lawsuit or anti-toxics activism at Love Canal. Only a few mention Black Lake or the political context from which it emerged. ${ }^{4}$

\footnotetext{
${ }^{2}$ William B. Ratliff, "Preamble" to "Environment and the Poor" workshop, proceedings, "Working for Environmental and Economic Justice and Jobs" conference, May 6, 1976, folder 12, box 10, UAW-CRD; A. Philip Randolph Institute, A "Freedom Budget" for All Americans: A Summary (New York, 1967).

${ }^{3}$ Judith Stein, Pivotal Decade: How the United States Traded Factories for Finance in the Seventies (New Haven, CT, 2010), xi; Lily Geismer, Don't Blame Us: Suburban Liberals and the Transformation of the Democratic Party (Princeton, NJ, 2015), 1-2; Michael Stewart Foley, Front Porch Politics: The Forgotten Heyday of American Activism in the 1970s and 1980s (New York, 2013), 8-9, 95-178; Jefferson Cowie, The Great Exception: The New Deal and the Limits of American Politics (Princeton, NJ, 2016), 191. Foley notes, however, that the activism he describes often transcended "NIMBYism," and involved collective action and demands on the state. Foley, Front Porch Politics, 9.

${ }^{4}$ See, for example, Eileen McGurty, Transforming Environmentalism: Warren County, PCBs, and the Origins of Environmental Justice (New Brunswick, NJ, 2009) and Robert D. Bullard, Dumping in Dixie: Race, Class, and Environmental Quality, 3rd ed. (Boulder, CO, 2000), 1-36. The most detailed published account of the Black Lake conference is Margaret Allen and Philip Perkins, "Working for Environmental and Economic Justice and Jobs," in Thunder at Michigan and in the Heartland: Working for Student Empowerment and Action, ed.
} 
The purpose of this article is not to claim that Black Lake was the "origin" of the environmental justice movement, or to downplay the importance of events highlighted in conventional environmental justice narratives. Rather, it connects those events to a largely forgotten history of collaboration across social movements. It also highlights differences between earlier and later formulations of environmental justice. In the mid-1970s, activists such as William Ratliff not only challenged disproportionate pollution exposures when they called for "environmental justice." They also advocated government planning for full employment as well as large-scale job creation in renewable energy, recycling, weatherization, and environmental clean-up programs, which would prioritize the most polluted, impoverished, and segregated communities. By reducing workers' fear of unemployment, these activists argued, full employment policies could enable unions and civil rights groups to collaborate more with environmentalists.

Nevertheless by the mid-1980s, all three components of the labor-civil rights-environmental coalition found themselves on the defensive, crippled by plant closures, urban disinvestment, and the Reagan administration's attacks on unions and environmental and civil rights laws. The emergence of a professionalized "CEO culture" in national environmental organizations, as well as the shift to concessionary bargaining by labor unions, also steered many toward narrower political agendas. ${ }^{5}$ In this context, activists in low-income communities of color, with few expectations of help from federal or state governments, took up the banner of environmental justice in local battles over toxic waste, dioxin-spewing incinerators, and other health threats. As hopes for federal and state policy support receded, the social-democratic ideas that emerged from Black Lake retreated from environmental justice activism and scholarship. Revisiting this forgotten history of coalition politics, then, does more than challenge standard periodizations of the environmental justice movement. It resituates the movement within the larger socialdemocratic politics of the 1970s, and reveals how the defeat of those politics transformed the terms of national debate about jobs, racial justice, and the environment.

\section{Pollution, Jobs, and Urban Poverty}

Between 1950 and 1970, Wayne County (encompassing Detroit and its industrial suburbs) lost 235,000 manufacturing jobs, while four nearby counties gained 123,000. Between 1970 and 1983, metropolitan Detroit lost another 100,000 manufacturing jobs. Only 62,000 remained by 1990 . Although Detroit's deindustrialization began in the 1950s and 1960s, the 1970s proved a particularly wrenching decade, as two of the worst recessions since the Great Depression coincided with accelerating population loss and a collapsing tax base. Demographically, the proportion of Detroit's population classified as "white" fell from 55.5 to 34.4 percent. Hundreds of thousands of white residents relocated to suburbs, which excluded African Americans through a combination of redlining, racial steering, restrictive zoning, and harassment and intimidation of black homebuyers. This rapid hemorrhaging of capital and population from Detroit produced a municipal fiscal crisis, forcing the city's first African American mayor, Coleman Young, to implement a series of draconian austerity budgets. The socioeconomic gap between

Bunyan Bryant (New York, 2009), 33-40; also see Robert Gordon, "Environmental Blues: Working-Class Environmentalism and the Labor-Environmental Alliance, 1968-1985" (Ph.D. diss., Wayne State University, 2004), 214-29. A few other historians have noted the importance of Black Lake. See, for example, Robert Gottlieb, Forcing the Spring: The Transformation of the American Environmental Movement, rev. ed. (Washington, DC, 2005), 370-2; Chad Montrie, Making a Living: Work and the Environment in the United States (Chapel Hill, NC, 2008), 103-6; and Robert Gioielli, Environmental Activism and the Urban Crisis: Baltimore, St. Louis, Chicago (Philadelphia, 2014), 152-3.

${ }^{5}$ Gottilieb, Forcing the Spring, 161-217; Jennifer Thomson, "Surviving the 1970s: The Case of Friends of the Earth," Environmental History 22, no. 2 (2017): 235-56; Kim Moody, An Injury to All: The Decline of American Unionism (New York, 1988), 165-92. 
the city and its suburbs widened, as poverty rates in Detroit grew from three times the suburban level in 1970 to four times that level in $19800^{6}$

The economic crises of the 1970s also altered the terms of debate about industrial pollution and environmental regulations in Detroit. The city served as the headquarters for the United Auto Workers (UAW), one of the nation's largest labor unions, whose membership reached a historic peak of 1.5 million members in 1979. Since World War II, the UAW had been one of the most pro-environmental unions in the United States, supporting a range of causes from industrial pollution control to working-class recreational programs and environmental education. Walter Reuther, the president of the UAW from 1946 to 1970, raised concerns about radiation from the Enrico Fermi Atomic Power Plant in the 1950s, and supported the raft of environmental bills signed by Presidents Johnson and Nixon. Reuther's UAW also provided funding for the first Earth Day, which attracted over 20 million participants on April 22, 1970, and organizations such as Environmental Action, founded the same year. ${ }^{7}$

The UAW was also active in environmental politics in metropolitan Detroit. On October 9, 1969, the severely polluted Rouge River (downstream from the Ford Motor Company's River Rouge factory complex) caught fire, only four months after the more infamous conflagration of Cleveland's Cuyahoga River. In the following months, Olga Madar and other staff members in the UAW Conservation and Recreation Department organized a network of Conservation Committees, which served as member-run standing committees within UAW locals. In December 1969, members of UAW Locals 2, 15, 22, 157, 174, 387, and 600 joined local environmental organizations to form the Downriver Anti-Pollution League (DAPL). ${ }^{8}$

The new organization focused on the industrial corridor southwest of Detroit, where the Detroit and Rouge Rivers carried much of the region's industrial waste and untreated sewage into Lake Erie. DAPL held its first official meeting on March 25, 1970, the month before Earth Day. DAPL activists packed city council meetings and zoning board hearings, and picketed a meeting of the Michigan Water Resources Commission (MWRC) in February 1970. During the MWRC protest, Peter D. Naccrato of UAW Local 2 told the Detroit News, "We're dramatizing the urgent need for an immediate halt to the excessive pollution being dumped into the air and water of downriver communities by Ford, Great Lakes Steel, and others."

UAW members also raised concerns about Detroit's inner-city environmental problems. At one meeting at a Detroit local, an African American auto worker complained to a Conservation Committee member that the union was supporting environmental initiatives in farflung areas, while neglecting more severe problems in the inner city. He cited the example of

\footnotetext{
${ }^{6}$ Joe T. Darden, Richard Child Hill, June Manning Thomas, and Richard Thomas, Detroit: Race and Uneven Development (Philadelphia, 1987), 67-108; Reynolds Farley, Sheldon Danziger, and Harry J. Holzer, Detroit Divided (New York, 2000), 53-106; Andrew James Jacobs, "Intergovernmental Relations and Uneven Development in the Detroit and Nagoya Auto Regions" (Ph.D. diss., Michigan State University, 1999), 66-100; Philip J. D. Anieri, "Regional Reform in Historic Perspective: Metropolitan Planning Institutions in Detroit, 1950-1990" (Ph.D. diss., University of Michigan, 2007), 81-4.

${ }^{7}$ Jacqueline Hamm Southern, "Labor, Environmentalism, and the Public Interest: The United Auto Workers in the Quiet Decade” (Ph.D. diss., Clark University, 2009); Montrie, Making a Living, 91-112; Brandon Ward, "Detroit Wild: Race, Labor, and Postwar Urban Environmentalism” (Ph.D. diss., Purdue University, 2014), 10139; Josiah Rector, "Accumulating Risk: Environmental Justice and the History of Capitalism in Detroit, 18802015” (Ph.D. diss., Wayne State University, 2016), 164-255.

${ }^{8}$ Marcellius Ivory, Bard Young, and Olga Madar, Letter to Local Union Presidents, Regions 1A and 1E, Dec. 2, 1969, folder 23, box 2, Olga Madar Collection, Reuther Library; “Citizens Plan Anti-Pollution Mass Meeting," River Rouge Herald, Mar. 25, 1970; "Downriver Group Fights Pollution,” River Rouge Herald, Aug. 12, 1970, clippings in folder 11, box 2, UAW-CRD; John H. Hartig, Burning Rivers: Revival of Four Urban-Industrial Rivers That Caught on Fire (Burlington, Ontario, 2010), 11-21.

"James L. Kerwin, "Pickets Urge Crackdown on State Water Polluters," Detroit News, February 19, 1970, 18A; "UAW Seeks to Bridge Communications Gap with Water Resources Commission," News from the UAW, Mar. 11, 1970, folder 14, box 11, UAW-CRD.
} 
Escanaba, a popular vacation spot in Michigan's Upper Peninsula, where the UAW Conservation and Recreation Department (UAW-CRD) supported efforts to reduce air pollution from pulp mills. "We got big problems-we got rats, we got lead poisoning, we got garbage piled up," he observed, "and you're talking about us getting excited about clean air in Escanaba." If the union targeted the environmental health hazards that threatened African Americans in Detroit, UAW-CRD staffers observed, even "resisters" might become "ardent environmental activists."

Public health studies in the early 1970s revealed that these hazards had severe consequences, particularly for families living in older housing stock. According to a 1973 study by the Detroit Health Department, 10 percent of Detroit children had "abnormal levels of lead in their blood," and an estimated 80,000 Detroit children between the ages of one and five faced "a high risk of being lead poisoned." Although the city did not categorize the results by "race," the majority of these children were African Americans living in neighborhoods with heavy concentrations of lead-laced automotive exhaust, lead emissions from industrial sites, and homes with lead paint. Childhood lead poisoning caused elevated risks of "retardation, neurological damage, learning disabilities, abnormal behavior problems, epilepsy, palsy, paralysis and blindness."11

The same year, the Center for Health Statistics at the University of Michigan School of Public Health reported that life expectancy for African American men in Michigan had fallen from 64 years in 1960 to 61.4 years in 1970, even as it rose for all other groups. The director of the Center, Dr. Kurt Gorwitz, singled out black men's concentration in hazardous "lower-level occupations," such as work in dusty automobile foundries, as a factor in high mortality rates. These problems were not limited to Detroit or to African Americans. In 1972, the National Institute of Occupational Safety and Health estimated that in the United States "there may be as many as 100,000 deaths per year from occupationally caused diseases." These maladies resulted primarily from exposure to dust and toxic chemicals in mines, factories, and farmers' fields. Far from being a "posteconomic" issue, industrial pollution increased workers' medical bills and lowered property values for inner-city residents. More important, it was a matter of life and death, especially for people of color segregated in the worst jobs and housing. ${ }^{12}$

But even as public health studies produced damning evidence of industrial pollution's effects, capital mobility gave corporations a powerful tool to divide workers and environmentalists. In 1971, for example, Chrysler officials threatened to shut down Detroit's Huber Foundry, which employed an estimated 3,000 workers. The foundry, the first large factory opened in Detroit since 1955, faced environmental lawsuits from angry neighborhood residents, including UAW retirees. Chrysler threatened to close the foundry if Wayne County officials enforced the Michigan Air Pollution Control Act. Similarly, in Tarrytown, New York, General Motors officials threatened to relocate operations to Baltimore if the Environmental Protection Agency forced it to cease dumping PCBs and other toxic chemicals into the Hudson River. In Marietta, Ohio, Union Carbide threatened to lay off 600 workers if new state and federal air quality standards increased pollution control costs. In a growing number of communities, plant closure threats pressured elected officials and union leaders to side with corporations in environmental battles. ${ }^{13}$

\footnotetext{
${ }^{10}$ UAW Conservation and Recreation Department, "United Community Action for Environmental Education of Workers and Citizens," Mar. 1974, 19-23, file 29, box 2, Olga Madar Collection, Reuther Library.

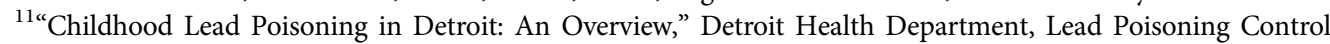
Program, Herman Kiefer Hospital Complex, n.d. [1973], 1, Library of Michigan, Lansing, MI; Dolores Kate, "Lead Poison Perils Inner City Children: 10 Victims Sent to Hospitals," Detroit Free Press, Feb. 19, 1972, A1; clipping in Folder 40, Box 32, Detroit Commission on Community Relations collection, Reuther Library.

${ }^{12}$ Betty DeRamus, "Is Hard Living Killing Off Black Men at an Early Age?" Detroit Free Press, Feb. 5, 1973, 1A, 2A; United States Department of Health, Education, The President's Report on Occupational Safety and Health (Washington, DC, 1972), 111.

${ }^{13}$ Julia Morris and the United Auto Workers Conservation and Recreation Department, The Huber Avenue Story: What Pollution Has Cost a Community (Detroit, 1970), folder 22, box 5, UAW-CRD; "Woodcock Urges
} 
The 1970s in particular tested UAW leaders' commitment to environmentalism. On May 9, 1970, Walter Reuther died in a plane crash en route to the Walter and May Reuther Education Center in Black Lake, Michigan. Reuther had conceived of that \$30 million facility while touring the Swedish Confederation of Trade Unions's worker education centers. The wooded lakeside complex, 260 miles north of Detroit, became a center for UAW environmental education, featuring wilderness trails, a windmill, and solar heating systems. Leonard Woodcock, a Reuther loyalist on the UAW Executive Board since 1955, kept Reuther's commitment to environmental causes alive while serving as UAW President from 1970 to 1977. But environmentalism in the UAW was not merely a top-down affair led by the older white males of the union's officialdom. It also emerged from activism in UAW locals, including from African American health and safety advocates who accused the union of failing to protect black workers from lethal conditions in Detroit factories. ${ }^{14}$

UAW leaders recognized that capital mobility had altered the politics of pollution control. In the early 1970s, they lobbied Congress for an amendment to the Public Works and Economic Development Bill (H.R. 16071) to grant workers the right to sue employers if their plants closed due to environmental law violations. In testimony before the U.S. Senate on May 18, 1971, Woodcock argued that the bill would "smoke out the environmental blackmailers." In 1972, however, President Nixon vetoed H.R. 16071, declaring that the employer liability provisions "would be highly inequitable and almost impossible to administer." In October, Woodcock told the press that "Mr. Nixon has given the green light to environmental blackmailers who use workers as pawns in resisting clean air and water standards." 15

At a conference at the University of California-Berkeley on November 28 of that year, Woodcock acknowledged the limitations of a litigation-focused strategy. In the long term, he argued, avoiding "jobs versus the environment" dilemmas would require increasing public control over investment decisions. Rather than leaving the fate of workers and their communities up to "the large, socially indifferent, and intransigent corporation," Woodcock told the attendees, workers should demand a say through "democratic national planning." This phrase was nothing new. While serving on the War Labor Board during World War II, Walter Reuther used the phrase "national planning" to refer to tripartite, corporatist production arrangements. In the 1960s, Reuther had unsuccessfully urged President Johnson to establish a "democratic planning agency," on the model of Sweden's Social Democratic Party, to eliminate poverty and unemployment. ${ }^{16}$

It was only a small step, then, for UAW leaders to associate social-democratic planning with an equitable environmental policy. In this respect, they followed the precedent of the Freedom

Environmentalists to Support Labor's Fight to Reduce Workplace Pollution,” News from the UAW, Nov. 15, 1975, folder 8 , box 36 , UAW-CRD.

${ }^{14}$ Nelson Lichtenstein, The Most Dangerous Man in Detroit: Walter Reuther and the Fate of American Labor (New York, 1995), 436-8. On pollution and African American health and safety activism in Detroit, see Josiah Rector, "Environmental Justice at Work: The UAW, the War on Cancer, and the Right to Equal Protection from Toxic Hazards in Postwar America," Journal of American History 10, no. 2 (Sept. 2014): 480-502, here 491-3.

${ }^{15}$ Leonard Woodcock, "Testimony before the U.S. Senate Committee on Public Works and Environmental Control, Hearings on Economic Impact of Environmental Control Requirements," May 18, 1971, folder 1, box 239, Leonard Woodcock Collection, Reuther Library; "UAW Hits Nixon Veto of Legislation to Aid Workers in Pollution Layoffs," News from the UAW, Oct. 27, 1972, folder 35, box 8, UAW-CRD. For Nixon's public statement, see Richard M. Nixon, Public Papers of the President of the United States: Richard M. Nixon, 1972 (Ann Arbor, MI, 2005), 376.

${ }^{16}$ Leonard Woodcock, "Labor and the Economic Impact of Environmental Control Requirements," paper presented at "Jobs and the Environment-Whose Jobs? Whose Environment?" conference, Institute of Industrial Relations, University of California-Berkeley, Nov. 28, 1972, 10, http://www.oac.cdlib.org/ark:/28722/bk0003s9447/? brand=oac4 (accessed Sep. 27, 2017); Kevin Boyle, The UAW and the Heyday of American Liberalism, 1945-1968 (Ithaca, NY, 1995), 187-8; Lichtenstein, The Most Dangerous Man in Detroit, 392. 
Budget, written by A. Philip Randolph, Bayard Rustin, and a small team of labor- and civil rights-affiliated social scientists in 1965-1966 and published in 1967. Randolph and his colleagues argued that government planning for full employment, and the expansion of the welfare state, could achieve the "abolition of poverty" in the United States by 1975. The authors also incorporated environmental improvement into their vision. "Air and waters remain polluted," they observed. "Recreation facilities remain unavailable for those who need them most." Calling for "recreational facilities available to all," they argued that sufficiently funded "programs of resource conservation and replenishment would provide millions of jobs, and, as in the case of housing and urban renewal, would have the additional merit of a high product mix of relatively less-skilled jobs."17

These proposals drew on a generation of labor-liberal thought about unemployment and the public sector. In the 1930s and 1940s, New Deal jobs programs and wartime defense production offered a precedent for massive reductions in unemployment through aggressive federal government action. From the debate over the Full Employment Bill of 1945 until Humphrey-Hawkins in the 1970s, supporters of full employment invoked these precedents, arguing that a federal job guarantee could both prevent another Great Depression and keep employment below a low threshold. In the mid-1970s, government planning for full employment remained a core demand of the labor and civil rights movements. Leading welfare rights activists and feminists also supported full employment, even as they critiqued the sexist assumptions underlying the male breadwinner model, and demanded increased income supports for those outside the paid labor force. ${ }^{18}$ However, the altered economic conditions of the mid-1970s intensified business opposition to full employment, unions, welfare, and government regulations. Beginning in 1968, labor militancy, rising international economic competition, and inflation contributed to falling profit rates for non-financial corporations. Increasing capital mobility, the use of anti-union consulting firms, and investment in anti-tax and anti-regulatory lobbying activity all emerged as responses to this problem. ${ }^{19}$

The OPEC oil embargo of 1973-1974, provoked by the Nixon administration's support for Israel in the Yom Kippur War, led to a tripling of oil prices, and increased demand for more fuel-efficient Japanese and European cars. In Congressional hearings and meetings with the Nixon administration, auto executives blamed environmental regulations for the industry's downturn. In December 1973, GM paid for full-page advertisements in the New York Times, asserting that lowering EPA air quality standards to 1969 levels would "save billions of gallons of gas." That month, the Senate passed a bill delaying the 1975 Clean Air Act standards until 1977. These delays would allow cars produced in 1975-1977 to produce emissions four times higher than permitted before the 1970 Clean Air Act was enacted. Meanwhile, as auto sales fell to their lowest levels since the 1958 recession, American automakers laid off over 300,000

\footnotetext{
${ }^{17}$ A. Philip Randolph Institute, Freedom Budget, 53-54; Paul Le Blanc and Michael D. Yates, A Freedom Budget for All Americans: Recapturing the Promise of the Civil Rights Movement in the Struggle for Economic Justice Today (New York, 2013), 89-126.

${ }^{18}$ Marisa Chappell, The War on Welfare: Family, Poverty, and Politics in Modern America (Philadelphia, 2010), 106-55; Margaret Weir, Politics and Jobs: The Boundaries of Employment Policy in the United States (Princeton, NJ, 1992), 27-162; Helen Lachs Ginsburg, "Historical Amnesia: The Humphrey-Hawkins Act, Full Employment and Employment as a Right," Review of Black Political Economy 39, no. 1 (Mar. 2012): 121-36.

${ }^{19}$ Judith A. Layzer, Open for Business: Conservatives' Opposition to Environmental Regulation (Cambridge, MA, 2012), 31-82; Meg Jacobs, "The Politics of Environmental Regulation: Business-Government Relations in the 1970s and Beyond," in What's Good for Business: Business and American Politics Since World War II, eds. Kim Phillips-Fein and Julian Zelizer (New York, 2012), 212-32; Benjamin Waterhouse, Lobbying America: The Politics of Business in America from Nixon to NAFTA (Princeton, NJ, 2014), 174-200; Joe Greene Conley, "Environmentalism Contained: A History of Corporate Responses to the New Environmentalism" (Ph.D. diss., Princeton University, 2006), 144-202; David Kotz, The Rise and Fall of Neoliberal Capitalism (Cambridge, MA, 2015), 45-84.
} 
workers, including 175,000 UAW members. In November 1974, Chrysler announced plans to temporarily close all of its North American assembly plants from the day before Thanksgiving until January 6, 1975. In 1968, the unemployment rate in Detroit had been 4 percent. By 1973, during the first "oil shock," it reached 11.5 percent; by 1974 it climbed to 14 percent, and then to a staggering 23.6 percent in $1975 .^{20}$

These developments increased pressure on UAW leaders to side with auto manufacturers on environmental questions. At the federal level, they aided the Big Three in a second round of lobbying to delay the 1977 Clean Air Act emissions standards. In Senate hearings in May 1975, Leonard Woodcock argued that these delays would put UAW members back to work without "endangering public health." The energy crisis, Woodcock said, had caught the Detroit automakers by surprise. When Senator John C. Culver (D-IA) asked whether this raised doubts about auto executives' business sense, Woodcock stressed, "I worry not about the General Motors Corp. and Ford and Chrysler. I worry about the city of Detroit where I live and the 23.6 percent unemployment rate." As the Wall Street Journal noted in August, these UAW efforts won over liberals in Congress to the emissions delays. $^{21}$

In this worsening economic context, labor and civil rights leaders became more critical of the environmental movement. This included Bayard Rustin, despite the environmental reforms he himself had endorsed in the Freedom Budget. In a September 1975 press release, Rustin acknowledged that "blacks and working people" suffered disproportionately from "environmental degradation." But he argued that "environmentalists are militant mainly about threats to rural peace and wildlife and their beloved vacation spots, while tending to ignore the far more desperate problems of the urban environment in which most Americans live." Still, he conceded that "strong environmental controls" must be placed upon corporations. In the New York Times, Rustin praised environmentalists for "[p]ointing out how it is the neighborhoods of the poor and working classes which receive the worst effects of pollution from nearby plants," which had "added an important class dimension to the struggle for a cleaner environment." Rustin's problem was not environmentalism per se, but the "class and racial bias" of mainstream environmental organizations. ${ }^{22}$

Meanwhile, the UAW remained internally divided on environmental questions. Even as the UAW Executive Board sided with automakers in calling for delays in federal auto emissions standards, the UAW-CRD continued to fund and collaborate with environmental organizations. While UAW-CRD staffers did not criticize the Executive Board position, they also encouraged auto workers to challenge corporate polluters, including the Detroit automakers. In 1974, with funds from the Office of Environmental Education, in the Department of Health, Education, and Welfare, the UAW-CRD developed a project called "United Community Action for Environmental Education of Workers and Citizens." The project was an environmental education program for union members, focused on pollution and recreation issues facing workers and urban residents. As department staffers noted, the 1973-1974 layoffs had "provided a new twist" on industry's longstanding practice of “environmental blackmail."

\footnotetext{
20"Chrysler to Close Five Plants," The Washington Post, Nov. 20, 1974, A1; "Detroit on the Brink of Depression," The Washington Post, Nov. 25, 1974, A3; Leonard Woodcock, testimony before U.S. Congress, Senate, Hearings Before the Subcommittee on Environmental Pollution of the Committee on Public Works, 94th Congress, 1st Session, May 17, 1975, 288.

${ }^{21}$ Ibid.; "UAW Position Paper on Federal Standards for Auto Emissions and Fuel Efficiency," May 6, 1975, Ibid., 300-321; Walter Mossberg and Charles Camp, "Power Drain: UAW, Hurt by Drop in Auto Employment, Faces Loss of Influence," Wall Street Journal, Mar. 12, 1975, 1, 24; James P. Gannon, "Business Blitz: Aided By Lobbyists, Corporations Avert 'Disaster' in Congress," Wall Street Journal, Aug. 5, 1975, 1, 27.

${ }^{22}$ Bayard Rustin, "The Environment and Economic Growth," A. Philip Randolph Institute News Release, Sept. 18, 1975, folder 36, box 8, UAW-CRD; Bayard Rustin, "No Growth Has to Mean Less Is Less," New York Times Magazine, May 2, 1976, 72-80; Environmental Action, May 22, 1976, 11.
} 
With 175,000 UAW members laid off, the International Union was losing $\$ 300,000$ per month in revenues; UAW locals were losing $\$ 400,000$. UAW-CRD staffers recognized that "the union must necessarily be guarded about its commitment of funds to new projects in the light of possible further layoffs and reduced union income." 23

Auto workers, union staffers recognized, were all too aware that exposure to toxic pollutants increased their risk of cancer, heart disease, silicosis, and other ailments. In an interview about African American foundry workers with the Detroit Free Press in 1973, Philip C. Sims of the Trade Union Leadership Council observed that "a lot of them go out with kidney disease at 42 or 43. They go on pension for the rest of their lives with less than half what they would have got if they continued working." A typical foundry worker earned $\$ 8$ per hour, including $\$ 5$ in wages (or $\$ 24.85$ in 2017 dollars) and $\$ 3$ in fringe benefits. While occupational diseases shortened workers' lives, by years or even decades, they often had long latency periods. By contrast, the loss of a high-wage union job immediately threatened workers' ability to support themselves and their families. In UAW Conservation Committees, members expressed anger about the toxic chemicals and dust they breathed every day, but also experienced "increasing anxiety due to job blackmail threats." 24

In their efforts to reconcile environmentalism with working-class and inner-city economic concerns, members of the UAW-CRD engaged in innovative coalition building. Between 1974 and 1976, they brought together members of UAW Conservation Committees, along with members of Detroit's Community Action Program (CAP), to outline a series of conferences at the Black Lake center. The most ambitious of these events, entitled "Working for Environmental and Economic Justice and Jobs: A National Action Conference," would be held from May 2-7, 1976, bringing together over 350 participants from 140 different organizations. The conference received $\$ 20,600$ in total contributions from the Communications Workers of America, the UAW, and the United Steelworkers of America, as well as from the Audubon Society, the National Wildlife Federation, the Ford Foundation, and anonymous donors. The Ford administration's EPA also provided over $\$ 10,000$ in funds. The event attracted national media coverage, including reporters from the New York Times and National Public Radio. ${ }^{25}$

The conference planning committee included representatives from twenty-four civil rights, labor, environmental, religious, and community organizations. As an Urban Environment Conference (UEC) report observed, Black Lake drew participants "from labor, industry, native Americans, southern mountaineers, blacks, chicanos, welfare rights activists, League of Women Voters leaders, and many more." Numerous civil rights activists joined in the wide-ranging discussions about environmental and economic justice and jobs, including Norman Hill of the A. Philip Randolph Institute, who had marched for voting rights at Selma, and who helped organize the 1968 Memphis Sanitation Workers's strike; Norman Harris, Jr. and Hiawatha Davis of Denver, Colorado's Eastside Action Movement; Norman Daniels and Walter Tytus of the Urban League; Lillian Benbow of the Michigan Civil Rights Commission; and Gerald

\footnotetext{
${ }^{23}$ UAW Conservation and Recreation Department, "United Community Action for Environmental Education of Workers and Citizens," Mar. 1974, 1-54, folder 29, box 2, Olga Madar Collection, Reuther Library.

${ }^{24}$ Ibid.; DeRamus, "Is Hard Living Killing Off Black Men?"; Franklin Wallick, "Labor: Paying a Price," Equilibrium (July 1974), 22-25, folder 35, box 8, UAW-CRD. The inflation-adjusted wage estimate is based on Bureau of Labor Statistics, “CPI Inflation Calculator," https://data.bls.gov/cgi-bin/cpicalc.pl (accessed Sept. 27, 2017).

25“The Spirit of Black Lake," Environmentalists for Full Employment no. 3 (Fall 1976), 1-3, folder 23, box 21, Environmentalists for Full Employment Series (hereafter EFFE), Archives Service Center, University of Pittsburgh; John Yolton, "Summary Report of Conference Finances," folder 23, box 21, EFFE; "Conference Planning Committee," in "Summary of Conference Proceedings: Working for Environmental and Economic Justice and Jobs National Action Conference, May 2-6, 1976," folder 12, box 10, UAW-CRD; Allen and Perkins, "Working for Environmental and Economic Justice and Jobs," 33-40.
} 
Wilkinson of the National Indian Youth Council. Prominent feminists attended the conference, including Jean Mager Stellman of the Boston Women's Health Book Collective, and Mimi Booker and Pauline Alexanderson of the League of Women Voters. Labor unions, including the United Mine Workers of America (UMWA), the United Steelworkers of America (USWA), the Oil, Chemical and Atomic Workers (OCAW), and the Communication Workers of America (CWA), as well as environmental organizations, including the Sierra Club, the Wilderness Society, Friends of the Earth, and the Isaak Walton League, also sent representatives. $^{26}$

Many of the conference participants argued that economic, environmental, and civil rights issues could not be addressed separately. Rather, environmental policy needed to be linked to redistributive social policies at the federal level, beginning with full employment. One of the organizations on the planning committee, Environmentalists for Full Employment (EFFE), was a Washington, DC-based 501 (c)(3) that formed in 1975 with the goal of uniting labor unions and environmental organizations around an agenda of job creation in renewable energy and other "environmental" industries. The Humphrey-Javits bill, introduced the same year, proposed to reduce unemployment to 3 percent, using public works employment and other federal projects coordinated by an Office of National Planning. The Humphrey-Hawkins bill, a scaled-down version of Humphrey-Javits introduced in 1976, jettisoned the planning agency, but retained the full employment target. EFFE members, like Hazel Henderson and Richard Grossman, maintained that Humphrey-Hawkins would undercut the "jobs versus the environment" framework that industry used to divide the labor, civil rights, and environmental movements. ${ }^{27}$

At the Black Lake conference, as journalists reported, the Humphrey-Hawkins bill became one of the "main topics of interest." During workshops, participants discussed possibilities for job creation in the fields of conservation, pollution control, and wind and solar energy. Members of Environmental Action, Environmentalists for Full Employment, the Urban Environment Conference, and other groups also hoped the federal government would fund such projects through the National Employment Priorities Act and the Comprehensive Employment and Training Act. The UAW and other unions supported full employment legislation to boost working-class bargaining power and job opportunities. Many environmentalists at the conference, Deborah Baldwin of Environmental Action observed, supported Humphrey-Hawkins because "it might remove the threat of environmental blackmail from the corporations' arsenal." 28

The expressed need to reconcile environmental, civil rights, and labor concerns pulsed through the conference. On May 7, the Women's Caucus issued a statement, read by Ginny Collette, demanding support for Humphrey-Hawkins, which "should specifically address the employment problems of women and minorities." Norman Harris, Jr., speaking for the

\footnotetext{
26“Summary of Conference Proceedings: Working for Environmental and Economic Justice and Jobs: A National Action Conference" (May 2-7, 1976), i-ix, folder 12, box 10, UAW Conservation and Recreation Departments Collection (Reuther Library, Detroit, MI); "Labor, Environmentalists, Community Action Groups Work Together-Phil Hart's Inspiration," Congressional Record, July 1, 1976, 22215-6; Gladwyn Hill, "Labor Seeks Ties to Ecology Bloc," New York Times, May 9, 1976, 27; "New Alliance Will Unite Labor and Environmentalists," UAW Washington Report, May 10, 1976; John H. Sheridan, "Must an Environmental Push Threaten Blue-Collar Jobs?" Industry Week, May 10, 1976; "Jobs, Conservation Seen as Compatible," AFL-CIO News, May 16, 1976; Frances d'Hondt, “Jobs Versus Environment: Must There Be a Conflict?” UAW Solidarity, June 1976; all articles cited in 94 Cong. Rec. 0702 (1976), 22215-21.

${ }^{27}$ Environmentalists for Full Employment newsletter, June 11, 1976; Environmentalists for Full Employment, "Fact Sheet on Humphrey-Hawkins and Inflation," May 22, 1978," folder 40, box 18, EFFE; Richard Grossman, "Environmentalists and the Labor Movement," Socialist Review 15, nos. 4/5 (1985): 63-87. On Humphrey-Javits and Humphrey-Hawkins, see Stein, Pivotal Decade, 119-22, 190-2; Jefferson Cowie, Stayin' Alive: The 1970s and the Last Days of the Working Class (New York, 2010), 261-312.

${ }^{28}$ Deborah Baldwin, “They Said It Couldn't Be Done," Environmental Action, May 22, 1976, box 21, folder 24, EFFE; Hill, "Labor Seeks Ties to Ecology Bloc."
} 
Black Caucus, also endorsed Humphrey-Hawkins, while expressing the concern that unions with a history of job discrimination would oppose "retraining of minorities in the emerging environmental/energy industries." Harris argued that environmental campaigns against polluting facilities should include economic support for displaced industrial workers. At the same time, conference participants challenged industry claims about the employment effects of pollution regulations. In the conference keynote address, UAW President Leonard Woodcock argued that environmental and economic justice were inextricable. Urging support for Humphrey-Hawkins, he declared that full employment would give "corporate polluters ... a far more difficult time with environmental blackmail." ${ }^{29}$

Woodcock pointed out that there had been "few plant closings" because of EPA and OSHA enforcement. According to the EPA, firms in the United States had cited pollution control as a "significant factor" in 75 plant closings since 1971, involving an estimated 16,500 jobs. Even in such cases, involving less than 1 percent of total plant closings, employers often exaggerated the impact of regulations. A 1976 study by the OCAW, which helped organize the conference, found that "environmental considerations are generally not the overriding factor in the decision to close a plant facility." Corporate threats to close plants, then, were far more common than actual pollution-related shutdowns. At most, gutting EPA and OSHA regulations, as business leaders and conservative politicians called for, would have "delayed the inevitable" for the oldest, most technologically obsolescent facilities. ${ }^{30}$

As they debated the possibilities for a coalition between the civil rights, feminist, labor, and environmental movements, participants in the Black Lake conference articulated many of the demands and strategies that later guided environmental justice activism. At the end of the conference, participants joined hands to sing the union song "Solidarity Forever." Maintaining this spirit, however, would not be an easy task. Although some of the organizations present at Black Lake (particularly the United Church of Christ) would play a prominent role going forward, and some of the networks developed in and around the conference would deepen, including those between civil rights and environmental activists, inter-movement tensions nevertheless increased in the late 1970s and early 1980s. Most of the political reforms discussed in the conference's speeches and workshops would be defeated, while unions and environmental groups adopted an increasingly defensive posture in the face of mounting attacks from organized business and the political right.

\section{The Urban Environment Conference}

By the late 1970s, coalition-building efforts between labor, civil rights, and environmental organizations fell in large part to the Urban Environment Conference (UEC). Staffers in the office of Senator Phil A. Hart (D-MI) had founded the UEC in 1971, with the goal of uniting "urban groups from the fields of civil rights, labor and anti-poverty work with environmental organizations." The UEC worked with housing activists in Chicago and Baltimore on campaigns against childhood lead poisoning, and lobbied Congress for funds to support workers displaced by pollution-related plant closures. It received funding from the Southern Christian Leadership Conference, Black Survival, the National Welfare Rights Organization, Friends of the Earth, the

\footnotetext{
${ }^{29}$ Norman Harris, Jr., "A List of Black Concerns," May 4, 1976 proceedings, Working for Environmental and Economic Justice and Jobs Conference, Thursday-18; Lillian Benbow, speech transcript, proceedings, "Working for Environmental and Economic Justice and Jobs Conference," May 2, 1976, 2; Leonard Woodcock, speech transcript, proceedings, "Working for Environmental and Economic Justice and Jobs Conference," May 2, 1976, 2-7, all in folder 12, box 10, UAW-CRD.

${ }^{30}$ Woodcock, speech transcript, 2-7; Oil, Chemical, and Atomic Workers Union Research Department, Health, Safety, and Environmental Considerations as Factors in OCAW Plant Closings, 1970-1975 (Denver, 1976), 10, cited in Robert Gordon, "Shell No!': OCAW and the Labor-Environmental Alliance," Environmental History 3, no. 4 (Oct. 1998): 460-87, here 487 n. 62.
} 
Sierra Club, the UAW, and the Amalgamated Clothing Workers of America, among other organizations. Franklin Wallick, a longtime UAW occupational health activist and author of the 1972 book The American Worker: An Endangered Species, served on the UEC board of directors, and was an important contact with the union. ${ }^{31}$

In 1977, the UEC had received $\$ 66,000$ in grants, primarily from OSHA's New Directions program (launched by Carter appointee Dr. Eula Bingham), but also from the Rockefeller, Ford, and other foundations. Michele Tingling, an Urban League organizer from New York City recruited by the UEC that year, later recalled that these grants allowed the group to "build coalitions among environmentalists, minorities and occupational health organizers." Tingling and Darryl Alexander, both African American women, also worked with labor unions and the Urban League through the UEC to expand occupational health programs for "minority workers." The UEC launched environmental health education programs in Detroit, Baltimore, and Pittsburgh, and published the manual Inner City Health in America (1979), which proclaimed that "the possibility of strong major coalitions among environmentalists, health care workers, labor and civil rights groups" was "exciting." 32

In April 1979, the UEC, the Urban League, and the Sierra Club sponsored a new conference in Detroit, called City Care, a gathering that was larger and in some respects more impressive than the event at Black Lake. Some 750 participants from across the United States gathered at the Radisson Cadillac Hotel to listen to speakers who included Mayor Coleman Young and Michigan Governor William Milliken as well as high-ranking officials from federal agencies. The steering committee received grants from HUD, the EPA, the Department of the Interior, the Department of Agriculture, the Department of Energy, and the Department of Transportation. ${ }^{33}$

In her own speech, Michele Tingling recalled her suspicion of the environmental movement a decade before. While attending Wellesley College on a scholarship in 1968, she had been radicalized in the aftermath of Martin Luther King, Jr.'s assassination, joining a black student group and organizing protests on campus. At the time, she feared that environmentalism was a "nonpeople phenomenon, detracting energy, resources, and support from the civil rights/human rights movement." But since then, she said, "I have come to the realization that all forms of activity in which I have been involved-fighting for decent housing, for decent health care, for accountability in politics, for mass transportation-are environmental issues, as legitimate as are clean air and healthy workplaces.” Along with Ramon Rueda, a Puerto Rican organizer from the South Bronx involved in solar energy projects, she was proud to "claim the label of being an urban environmentalist." ${ }^{34}$

As they had at Black Lake, the conference working groups endorsed the goals of the Humphrey-Hawkins bill, passed the previous year. Unlike at the previous conference, however, and despite the attendance of representatives for the UAW and USWA, labor involvement at City Care was significantly smaller. Rather than government planning, many of the conference participants advocated neighborhood-level "self-help" and small public-private projects as

\footnotetext{
${ }^{31}$ Leonard Cooley, letter to the Urban Environment Conference Steering Committee, Mar. 10, 1972; Urban Environment Conference Press Release, Apr. 11, 1972; both in folder 9, box 31, Urban Environment Conference Collection (hereafter UEC), Reuther Library; Franklin Wallick, The American Worker: An Endangered Species (New York, 1972).

32"Proposal for Support of the Service for Minorities on Toxics Project of the Urban Environment Conference, Inc." Aug. 1981, folder 42, box 26, UEC; Michele Tingling, "From One Earth Day to the Next: Twenty Years of Action by People of Color," in We Speak for Ourselves: Social Justice, Race and Environment, ed. Dana Alston (Washington, DC, 1990), 22-3; Ellen Hall, Inner City Health in America (Washington, DC, 1979), 3, folder 45, box 28, UEC.

${ }^{33}$ Sydney Howe, "Following Up the 1979 City Care Conference: Support Sought for Multi-Interest Urban Environmental Program in Several Cities," Aug. 19, 1980, 1-5, folder 34, box 35, UEC.

${ }^{34}$ Remarks by Michele A. Tingling, City Care Conference, Apr. 11, 1979, Detroit, MI, 1-4, folder 46, box 2, UEC; Ramon Rueda, speech excerpt, "Proceedings: City Care, A National Conference on the Urban Environment," 11-2, folder 46 , box 2 , UEC.
} 
solutions to urban environmental problems. In the keynote address, Carter's Assistant Secretary for Neighborhoods, Monsignor Geno C. Baroni, framed an urban environmental agenda that broke decisively with New Deal liberalism and faith in the regulatory state. He declared that "big government, big business, big private sector, big public sector, has created a dependency that has to be shattered." Rather than "dependency," he called for embracing "a third sector, the voluntary sector, the non-governmental sector, the new neighborhood sector." Rather than full employment or labor law reform, he touted the benefits of the Neighborhood Self-Help Development Bill and the Livable Cities program. ${ }^{35}$

In a follow-up report, UEC staffers wrote optimistically that "City Care took a profound step forward in building a coalition between the environmental and civil rights movements" and "symbolized the growing concern of black groups for environmentally-caused health hazards as well as the shifting focus of environmentalists to urban problems." In a retrospective account in 1990, Tingling offered a less positive assessment. At City Care, she wrote, it became "clearer that the mainstream environmental movement" was "reluctant to address issues of equity and social justice, within the context of the environment." Nevertheless, Tingling remained committed to the UEC, and played a leading role in the organization's coalition-building efforts over the next five years. At a follow-up meeting in Racine, Wisconsin on June 6-7, 1979, the City Care steering committee planned to organize ten smaller regional conferences for that summer and fall, in cities ranging from Jackson, Mississippi to Dallas, Texas, Rochester, New York, and Los Angeles, California. ${ }^{36}$

The UEC-affiliated Human Environment Center also lobbied the Carter administration to expand CETA funds for inner-city "Youth-Conservation Employment," modeled on the New Deal's Civilian Conservation Corps and targeting the nation's 2.9 million unemployed youth between the ages of sixteen and twenty-four. They proposed jobs programs in solar installation, "weather-proofing" energy-inefficient buildings, recycling, pollution monitoring, and the construction and maintenance of new green spaces and recreation facilities in underserved urban areas across the country. But the idea of a new urban New Deal found little support in Congress or the White House. Civil rights and community organizations also faced a more challenging funding environment. As Sydney Howe of the Human Environmental Center wrote to the UEC on August 19, 1980, "we find consistently that the inability of participating groups to finance services, issue analysis, materials production, mailings, meeting arrangements, outside expertise and the like is the crucial limiting factor." Although the "spirit is strong," he lamented, "budgets are overladen."37

Following the City Care conference, the UEC became more involved in the problem of toxic pollution in low-income communities of color. In 1979, the UEC worked with Clyde Foster, mayor of the 99 percent African American town of Triana, Alabama, to publicize dichlorodiphenyltrichloroethane (DDT) contamination from a pesticide manufacturing plant. Between 1947 and 1971, the Connecticut-based Olin Corporation had dumped an estimated 4,000 tons of DDT into Indian Creek, where Triana's residents had fished for decades without knowing of the hazards. By 1980, the average resident had a DDT body burden nearly ten times higher than the general population. Residents suspected (but could not prove) that high rates of cancer, learning disabilities, and shorter than average statures in the town were linked to the exposures. In 1982, in a settlement with the Department of Justice under the Superfund Act, Olin paid \$24 million to 1,000 people living near the DDT dump. ${ }^{38}$

\footnotetext{
${ }^{35}$ Monsignor Geno C. Baroni, speech excerpt, "Proceedings: City Care," 6-7, folder 46, box 2, UEC.

36“Overview (or Summation)," Aug. 27, 1979, 2, folder 50, box 4, UEC; "Model City Care Local Follow-Up Conference, Mar. 31, 1981," "City Care" folder, box 50, UEC; Tingling, "From One Earth Day to the Next," 23.

${ }^{37}$ Human Environment Center, "Youth-Conservation Employment-Proposing Its Expansion and Describing Current Programs" (Nov. 1980), 1-17, folder 34, box 35, UEC; Howe, "Following Up the 1979 City Care Conference," $1-5$.

${ }^{38}$ Clyde Foster, testimony before the U.S. Senate Committee on Environmental Pollution, July 20, 1981; Clyde Foster, letter to George Coling, Aug. 26, 1981; Barbara Reynolds, “The Unhealthiest Town in America?" National
} 
Beginning in 1980, the UEC also organized the Memphis Toxics Project. Funded by a $\$ 10,000$ grant from the EPA, Tingling and other UEC staff provided technical assistance to the Cypress Health and Safety Committee and other community-based organizations opposing illegal dumping and toxic waste sites in African American neighborhoods in Memphis. "For over a year," UEC director George Coling wrote in 1981, "the Urban Environmental Conference has been assisting primarily black citizens' groups in Memphis to fight the threats from hazardous waste in their community." Out of more than one hundred toxic waste dumps in Shelby County, he noted, "their chief impact is on blacks." 39

\section{Deregulation, Deindustrialization, and the Volcker Shock}

By this time, however, the challenges facing such projects were mounting rapidly. The late 1970s and early 1980s witnessed a series of epochal shifts in federal employment, regulatory, and fiscal policy that undermined the labor-liberal-civil rights coalitions that emerged from the Black Lake and City Care conferences. In its final form the Humphrey-Hawkins bill had emerged as more symbolic than substantive. Like the Labor Law Reform Act, it had faced a well-funded opposition campaign by the Business Roundtable, the National Association of Manufacturers, and similar organizations. Through personal visits, letter-writing campaigns, and public criticisms in the media, lobbyists convinced legislators to remove key provisions from the bill. The final bill passed in October 1978 contained no federal commitment to job creation, and included instead an array of anti-inflation provisions, including the goal of reducing its rate to 0 percent by $1988 .{ }^{40}$ Environmental policy followed a broader trend of deregulation, evident in sectors ranging from trucking and airlines to railroads. In 1978, Carter required federal agencies to prepare a "regulatory analysis" of rules with "an annual effect on the economy of $\$ 100$ million or more," to be reviewed by a Regulatory Analysis Review Group. By delaying EPA and OSHA rule-making on asbestos, lead, and other hazards, regulatory reform reinforced industry efforts to block and dilute environmental standards. ${ }^{41}$

For the city of Detroit and the UAW, the shift from Keynesian to monetarist macroeconomic policies during the Carter administration, and the concomitant politics of inflation, proved highly significant. In 1978, the United States inflation rate hovered in the range of 6 percent, the lowest in the OECD. Between December 1978 and December 1979, however, the Iranian Revolution triggered a 150 percent increase in oil prices, and inflation rose to 13.4 percent. While this remained below the historic high of 1947, labor leaders recognized that inflation increasingly undercut working-class living standards. But they also challenged the tendency of corporate leaders to blame inflation on unions, social programs, and government regulations. In his 1978 resignation letter to President Carter's Labor-Management Group, UAW President Doug Fraser (who succeeded Leonard Woodcock in 1977), observed that

Wildlife Federation Magazine (Aug.-Sept., 1980), 33; Mary Thornton, “U.S., Olin Corp. Settle Industrial Dumping Suit," Washington Post, Dec. 31, 1982, A3, all in folder 42, box 5, UEC; Tingling, "From One Earth Day to the Next," 23.

${ }^{39}$ Michele A. Tingling to George Wood, Nov. 25, 1980, folder 3, box 28, UEC; Michele Tingling, letter to Frank Redmond, Mar. 24, 1981, folder 3, box 28, UEC; "We Cannot Afford to Lose Another Child," Cypress Health \& Safety Committee Newsletter, n.d., folder 3, box 28, UEC; George Coling to Don Martin, September 10, 1981, folder 64, box 6, UEC.

${ }^{40}$ Weir, Politics and Jobs, 130-62; Cowie, Stayin' Alive, 261-312; Waterhouse, Lobbying America, 130-2; Stein, Pivotal Decade, 149, 190-2.

${ }^{41}$ Jimmy Carter, "Executive Order 12044-Improving Government Regulations," March 23, 1978, http://www. presidency.ucsb.edu/ws/?pid=30539 (accessed Oct. 19, 2017); E. G. Vallianatos, Poison Spring: The Secret History of Pollution and the EPA (New York, 2014), 121-140, 177-188; Meg Jacobs, Panic at the Pump: The Energy Crisis and the Transformation of American Politics in the 1970s (New York, 2016), 161-195, 271-92; Conley, "Environmentalism Contained," 144-202. 
"business blames inflation on workers, the poor, the consumer, and uses it as a club against them." 42

Following withdrawal from the Labor-Management Group, Fraser co-founded the Progressive Alliance, which included over 100 labor, civil rights, feminist, environmental, and community organizations. The Progressive Alliance sought to challenge the Carter administration's embrace of austerity and deregulation, and advocated alternative policies for fighting inflation without increasing unemployment. In a May 1979 letter to the Progressive Alliance board of directors, Fraser argued that it was "possible to build a positive citizens' mass movement around the theme of fighting inflation in the necessities, and to tie that mass movement to the other goals of the Alliance." UAW, IAM, and other progressive unions supported a coordinated national incomes policy, involving wage and price controls negotiated by business, labor, and government leaders. They also provided funding to the Washington, DC-based nonprofit Consumers Opposed to Inflation in the Necessities (COIN). COIN members held that reducing inflation did not require abandoning long-term wage growth, full employment, or environmental and health safety regulations. Instead, COIN advocated sector-specific price controls, a national healthcare system to cut medical costs, expanded public investments in renewable energy, and aggressive anti-trust enforcement to break up price-gouging monopolies. But while oil price increases aroused large protests (as in "Big Oil Day" in October 1979), COIN's larger alternative strategy for fighting inflation lacked the support of a mobilized popular constituency. In contrast, Carter faced an increasingly well-organized business lobby that demanded aggressive action on inflation and staunchly opposed price controls for energy and other necessities. ${ }^{43}$

In August 1979, Carter appointed Paul Volcker to chair the Federal Reserve. Following a modified version of economist Milton Friedman's philosophy, which he called "practical monetarism," Volcker restricted the money supply by increasing capital reserve requirements for banks. He also hiked interest rates from 11.2 percent in 1979 to 20 percent in March 1980. Volcker's policies eventually brought inflation under control, but they also led to increased inflation in 1979-1980 and triggered the deepest recession in the United States since the Great Depression. ${ }^{44}$ The failure of Detroit's Big Three to invest in fuel-efficient cars, combined with high oil prices and a strong dollar, allowed Japanese automakers to increase their market share in the United States from 9.3 percent in 1976 to 20.9 percent in 1980. Rapidly losing sales and market share, the Big Three closed forty plants and 1,500 dealerships in 1980 alone. Between 1979 and 1982, UAW membership fell from 1,527,858 to 1,151,086, and would reach 867,564 by $1990 .{ }^{45}$

\footnotetext{
${ }^{42}$ Douglas Fraser, letter Labor-Management Group, July 17, 1978, folder 27, box 1, Douglas A. Fraser Collection, Reuther Library; Douglas Fraser, interview with Bertram Silverman, "Beyond Collective Bargaining," Challenge 22, no. 1 (Mar. 1979): 33-9; Allan H. Meltzer, A History of the Federal Reserve, vol. II, Book Two, 1970-1986 (Chicago, 2003), 1008-70; Iwan Morgan, "Monetary Metamorphosis: The Volcker Fed and Inflation," The Journal of Policy History 24, no. 4 (2012): 545-71; W. Carl Biven, Jimmy Carter's Economy: Policy in an Age of Limits (Chapel Hill, NC, 2002), 237-52.

${ }^{43}$ Doug Fraser to the Officers of the Progressive Alliance, May 4, 1979, folder "Progressive Alliance," box 13, EFFE; “Inflation Isn't a Natural Disaster: It's Caused by People Who Profit from It," Consumers Opposed to Inflation in the Necessities pamphlet (1978), folder 6, box 9, UEC; Andrew Battista, The Revival of Labor Liberalism (Urbana, IL, 2008), 83-102; “The Decontrol Program: What It Will Do," Citizen/Labor Energy Coalition, n.d., "Progressive Alliance" folder, box 13, EFFE; "Auto Workers Protest Energy Plans, Oil Gains," Battista, Revival of Labor Liberalism, 111.

${ }^{44}$ On Carter's selection of Volcker, see Morgan, "Monetary Metamorphosis," 552; Stein, Pivotal Decade, 227; David Rockefeller, Memoirs (New York, 2002), 369; Biven, Carter's Economy, 237-52.

${ }^{45}$ On the Volcker shock and American manufacturing, see Donald D. Hester, The Evolution of Monetary Policy and Banking in the U.S. (Heidelberg, Germany, 2008), 70. On auto plant closures, see Steve Babson, Ron Alpern, Dave Elsila, and John Revitte, Working Detroit: The Making of a Union Town (Detroit, 1986), 210-21; Stein, Pivotal
} 
When the "Volcker shock" began, Chrysler Corporation, the largest employer of auto workers in the city of Detroit, faced bankruptcy. Chrysler employed 37,000 Detroit residents, 7 percent of the city's total employment. While campaigning for a federal bailout, Chrysler CEO Lee Iacocca blamed federal environmental, safety, and fuel efficiency regulations for the firm's difficulties. During the bailout negotiations in 1979, Chrysler officials requested a two-year grace period for compliance with EPA regulations. Some congressional Democrats, such as Representative Henry Reuss (D-WI), proposed the opposite, requiring Chrysler to increase fuel efficiency and build parts for public transit vehicles. In July 1980, President Carter flew to Detroit and presented auto industry officials with a billion-dollar rescue package. As part of the deal, the EPA reduced automobile emission requirements, and OSHA relaxed standards on arsenic and lead levels in automobile factories. As part of its federal loan conditionalities, Chrysler closed five Detroit-area plants between 1979 and 1981. By 1982, unemployment in Detroit had reached 37.3 percent for African Americans and 26 percent for whites. ${ }^{46}$

\section{The Shifting Geography of Environmental Justice}

The election of Ronald Reagan in 1980 deepened the trends of fiscal devolution, urban austerity, and deregulation that began under Carter. Under Reagan, federal aid to cities fell by $\$ 26$ billion, a reduction of 46 percent. Reagan slashed CETA funding by one-third and eliminated its public works program in 1981. By 1984, the administration had reduced the EPA's staff by 22 percent, its research budget enforcement budget by half, and pollution control grants to states by 40 percent. Likewise, OSHA's budget fell by 30 percent, and the agency closed over one-third of its field offices. ${ }^{47}$

At Solidarity House in Detroit, UAW leaders faced intensified pressures for concessionary bargaining and fewer resources for coalition building. In 1982, the UAW executive board cut staff in the Conservation and Recreation Department in half, from twelve to six. The union's distance from environmental groups increased over the next decade, both at the local level and at the national level. Similarly, cutbacks in grant funding by the EPA and OSHA under Reagan forced the Urban Environment Conference (UEC) to downsize its operations in the early 1980s. In a July 1981 staff memo, UEC director George Coling wrote that the organization was in a "financial crisis" and faced a budget shortfall of $\$ 9,100$. In addition to laying off staff, the organization would need to rely more heavily on funding from private philanthropic foundations. By the end of 1982, the Reagan administration had reduced funds for OSHA's New Directions program by two-thirds, eliminating a crucial source of grant funding for UEC. Finally, in 1984, the UEC board shut down the organization due to lack of funding. ${ }^{48}$

Decade, 252-9; McCarthy, Auto Mania, 207-30; United Auto Workers Research Library, "UAW Membership Figures: 1936 through 2008" (in author's possession).

${ }^{46}$ U.S. Congress, Senate, Committee on Banking, Housing, and Urban Affairs, Hearings on the Chrysler Corporation Loan Guarantee Act of 1979, 96 Cong., 1st sess., Nov. 16-21, 1979, 1036-52, 1236-43; Stan Luger, Corporate Power, American Democracy, and the Automobile Industry (New York, 2000), 102-6; John D. Kasarda, Jürgen Friedrichs and Kay Ehlers, "Urban Industrial Restructuring and Minority Problems in the U.S. and Germany," in Ethnic Minorities and Industrial Change in Europe and North America, ed. Malcolm Cross (New York, 1992), 250-75, here 268.

${ }^{47}$ Stephanie Pollack and JoAnn Grozuczak, Reagan, Toxics and Minorities: A Policy Report by the Urban Environment Conference, Inc. (Washington, D.C., 1984), folder "Reagan, Toxics and Minorities," box 52, UEC; Ronald Smothers, "CETA Cutbacks Leaving Thousands Unemployed," New York Times, Apr. 11, 1981, A12; James Worsham, "Budget Slashing to Curtail Rules," Chicago Tribune, Mar. 15, 1981, 11B; Tom Horton, "Reagan Works on Environmental Image," The Baltimore Sun, July 15, 1984, 1B, 3B.

${ }^{48}$ Andy Feeney, "Empty Factories, Quiet Voices: Can the Unions Fight Job Losses and Still Take Strong Stands on the Environment?" Environmental Action 14, no. 4 (Oct./Nov. 1982): 21-4; George Coling, memo to UEC staff, July 29, 1981, folder 4, box 39, UEC; Gottlieb, Forcing the Spring, 338-9; Craig Slatin, Environmental Unions: Labor and the Superfund (Amityville, NY, 2009), 11-40. 
Before the end, however, the UEC organized one final major event: a three-day conference in New Orleans on November 18-20, 1983, entitled "Taking Back Our Health: An Institute on Surviving the Toxics Threat to Minority Communities," primarily funded by a $\$ 25,000$ grant from the Charles Stewart Mott Foundation. For the "first time," as Darryl Alexander wrote, the Institute would "gather minority grassroots leaders who have been fighting toxics battles with minority health professionals, labor leaders and heads of local and national organizations" to "formulate a coordinated strategy to confront the toxics issue on the state, local and federal level." The conference attracted over 200 activists from across the United States, of whom over half were people of color, the majority from Louisiana, Texas, Alabama, Mississippi, and Georgia. The conference also included activists from the West, Northeast, and Upper South working on uranium and toxic chemical poisoning in Navajo, Sioux, Mohawk, and Cherokee territories. During the conference, UEC's technical director presented awards to Dollie Burwell and Catherine Reavis, activists who had fought PCB dumping in Warren County, North Carolina, the year before. Another award recipient was James Ransom, who waged a similar battle against PCB dumping by General Motors at the Mohawk Reservation in upstate New York. ${ }^{49}$

In 1984, the same year UEC shut down, Environmentalists for Full Employment closed its doors as well. In the late 1970s and early 1980s, the EFFE had succeeded in forging connections between labor unions and environmental groups, including a series of labor-backed antinuclear protests following the Three Mile Island disaster. By the mid-1980s, however, the political and economic obstacles to labor-environmental coalitions had mounted significantly. In this context, the political and fundraising approaches of Washington, DC-based nonprofits like UEC and EFFE increasingly became ineffectual. And as polluting factories and toxic waste dumps moved south from the old industrial heartlands of the Northeast and Midwest, so too did the center of gravity of the environmental justice movement. ${ }^{50}$

In this respect, the struggle over PCB dumping in Warren County, North Carolina was characteristic of a national trend in the location of toxic waste. In 1978, long-haul trucks had illegally dumped an estimated 33,000 gallons of oil contaminated with PCBs on North Carolina roadways. After Governor Jim Hunt proposed dumping soil containing the PCBs in a landfill in majority-African American Warren County, a resistance movement began, linking local anti-toxics organizations with national civil rights groups. In September 1982, state troopers arrested over 500 activists for blocking the dump trucks with their bodies. Reverend James Orange of the Amalgamated Textile Workers was one of the protest organizers, and one of the key organizations involved (the United Church of Christ) had been present at Black Lake. Nevertheless, labor unions played a marginal role in the Warren County struggle, partly because union density in North Carolina was the second-lowest in the United States. ${ }^{51}$

Plant closures in the Rust Belt, meanwhile, did not mean the end of industrial pollution. Deindustrialization left cities like Detroit, East St. Louis, Gary, and Camden with tens of

\footnotetext{
${ }^{49}$ Urban Environment Conference, Inc., Resource Book from Taking Back Our Health: An Institute on Surviving the Toxics Threat to Minority Communities (Washington, DC, 1985), folder "Institute on Toxics and Minorities," box 52, UEC; Darryl Alexander, letter to Julia R. Scott, Aug. 16, 1983, folder 23, box 39, UEC; "Distribution of Participants," folder 24, box 39, UEC; "New Orleans conference follow-up; surveys," folders 16 and 20, box 44, UEC. On GM's PCB dumping in the St. Lawrence River, and its harmful effects on Mohawk communities, see Winona LaDuke, All Our Relations: Native Struggles for Land and Life (Cambridge, MA, 1999), 9-24.

${ }^{50}$ Carmen Brutto, "Laborites Plan Safe Energy March," The Patriot (Harrisburg, PA), Feb. 24, 1981; Ben A. Franklin, "Unions to Hold 'Peaceful' Protest on Three Mile Island Procedures," New York Times, Mar. 6, 1981, folder "Rally Clips," box 13, EFFE. On the end of EFFE in 1984, see Grossman, "Environmentalists and the Labor Movement," 82-7.

${ }^{51}$ On the role of Orange in the protests, see "PCB Foes Vow to Continue Sitdown Strike at Landfill," The Asheville Citizen-Times, Sept. 16, 1982, 1. On the protests, see McGurty, Transforming Environmentalism, 81-110. For the statistics, see Barry T. Hirsch, David A. Macpherson, and Wayne G. Vroman, "Union Density Estimates by State, 19642016," Monthly Labor Review, 2017, http://unionstats.gsu.edu/MonthlyLaborReviewArticle.htm (accessed Oct. 19, 2017).
} 
thousands of contaminated brownfield sites that they could not afford to clean up. Detroit's shuttered automobile plants no longer emitted smoke, but they contained unknown quantities of toxic heavy metals, asbestos, chemical waste, and other dangerous materials. As UAW industrial hygienist Michael Silverstein noted in a 1985 letter to the Detroit Free Press, the demolition of factories caused the "crushing and crumbling of asbestos," which could increase the risk of lung cancer and mesothelioma for workers and neighborhood residents who breathed the airborne fibers. Myriad other risks existed as well. In 1986, EPA officials found chemical spills from 200 drums and fifty vats leaking cyanide, lead, and other compounds at an abandoned Plating Equipment, Inc. factory in northeast Detroit. In 1989, the removal of lead-, zinc-, cadmium-, and petroleum-contaminated soils from a single abandoned Chrysler factory on Jefferson Avenue cost the city of Detroit over \$264 million. Brownfield site clean-ups thus became a final environmental cost that corporations externalized onto the public. $^{52}$

During the 1980s and 1990s, Detroit's Big Three offshored the most labor-intensive production processes, primarily to maquiladora zones in northern Mexico. Automakers, however, did not simply relocate production outside of the United States. They simultaneously increased investments in the rural and suburban Midwest, and across the South. Automation, right to work laws, and the spread of non-union plants (operated by both domestic and foreign automakers) were more responsible for declining UAW membership than offshoring. Nevertheless, the threat of plant closures continued to provide employers with a potent weapon against environmental and occupational health and safety activists. In maquiladora zones, multinational corporations could increase profits by externalizing the costs of unregulated pollution onto low-wage, predominantly female workers and surrounding communities. According to one estimate, environmental damage from maquiladora pollution cost Mexico \$36 billion per year between 1989 and 1999. ${ }^{53}$

Still, despite the rapid loss of manufacturing jobs and the Reagan administration's hostility to both unions and environmental organizations, organized labor continued to play an important role in the environmental justice movement in the 1980s. In many local communities, union health and safety activism provided a bridge for wider organizing against chemical poisons. The Silicon Valley Toxics Coalition connected the occupational health concerns of Asian and Latina chip plant workers with community organizations demanding the clean-up of computer industry dump sites leaking trichloroethane, arsenic, beryllium, and other compounds. In Geismar, Louisiana, OCAW members collaborated with African American community activists in Ascension Parish Residents Against Toxic Pollution and helped to organize the Gulf Toxics March in $1988 .^{54}$

Activism continued in the 1990s. Founded in 1990, the Southwest Network for Environmental and Economic Justice, an eight-state "coalition for people of color" organized campaigns against toxic dumping and OSHA violations by Intel and other corporations in the Southwest. Between October 24 and October 27, 1991, the First National People of

\footnotetext{
52"Demolition Can Be Deadly," Detroit Free Press, Apr. 8, 1985, 12A; Bob Campbell, "EPA Stops Toxic Leaks at Abandoned Factory," Detroit Free Press, Aug. 11, 1987, 4A; Constance Prater, "Taxpayers Face Higher Price for Chrysler Site and Cleanup," Detroit Free Press, July 12, 1989, 1A, 12A; Emily Askari and Dan Gilmor, "City Airport Cleanup Costs Could Escalate," Detroit Free Press, June 1, 1990, 1B, 8B; "City Aims to Calm Fear of Toxic Land," Detroit Free Press, Mar. 30, 1994, 1A, 12A.

${ }^{53}$ Nicole Aschoff, "Globalization and Capital Mobility in the Auto Industry" (Ph.D. diss., Johns Hopkins University, 2008), 46-78; Devon G. Peña, The Terror of the Machine: Technology, Work, Gender, and Ecology on the U.S.-Mexico Border (Austin, TX, 1997), 279-334; Chad Broughton, Boom, Bust, Exodus: The Rust Belt, the Maquilas, and a Tale of Two Cities (New York, 2015), 188-207; Sierra Club, "NAFTA's Impact on Mexico," http://vault.sierraclub.org/trade/downloads/nafta-and-mexico.pdf (accessed Oct. 19, 2017).

${ }^{54}$ David Naguib Pellow and Lisa Sun-Hee Park, The Silicon Valley of Dreams: Environmental Injustice, Immigrant Workers, and the High-Tech Global Economy (New York, 2002); Timothy Minchin, Forging a Common Bond: Labor and Environmental Activism during the BASF Lockout (Gainesville, FL, 2003); Peña, The Terror of the Machine, 135-77, 279-334.
} 
Color Environmental Leadership Summit took place in Washington, DC. The purpose of the event, sponsored by the United Church of Christ's Commission for Racial Justice, was to bring together activists challenging the concentration of environmental burdens in lowincome communities of color. More than 1,000 people attended the conference, hailing from a diverse range of locales: from Puerto Rico to Hawaii, New Mexico to South Dakota, and Mississippi to the Bronx. Some in attendance, like Bunyan Bryant of the University of Michigan School of Natural Resources, had participated in the UAW's Black Lake conference in 1976. Former UEC organizer Michele Tingling, now at the Alice Hamilton Occupational Health Center, was also a delegate. ${ }^{55}$ Although numerous labor activists attended the conference, merging the concerns of the labor and environmental justice movements was no easy task. During a Regional Group Workshop on the Midwest, Andrea Kidd-Taylor of the UAW noted that "threats of job cutbacks and plant closures have been very effective in preventing poor communities from joining together to confront occupational and environmental issues." 56

Some of the demands made at Black Lake-above all, full employment-were absent from the "17 Principles of Environmental Justice" drafted and adopted by the 1991 conference delegates. This reflected the diminished role of labor unions in the movement and the defeat of the social-democratic agenda associated with the Freedom Budget and Humphrey-Hawkins. This absence also influenced how scholars wrote about the environmental justice movement. Understandably, the first generation of social scientists to write about the movement, including scholar-activists such as Robert Bullard, who had been intimately involved since the 1970s, told a story that focused on the American South and Southwest. With some exceptions, unions and labor issues received little attention in that story. ${ }^{57}$

Three years after the 1991 conference, Donele Wilkins, Kathryn Underwood, and several other Detroit-based attendees joined to form another 501 (c)(3) nonprofit, Detroiters Working for Environmental Justice (DWEJ). In contrast to the organizations at the Black Lake and City Care conferences, DWEJ and other environmental justice nonprofits in the 1990s and 2000s had weaker ties to labor unions and received a larger proportion of their funding from private foundations. The landscape they operated in was also more challenging. By the early twenty-first century, Detroit was significantly more impoverished than in the 1970s. In 2008 , the city's unofficial unemployment rate reached nearly 50 percent. The child poverty rate in the city increased dramatically after the 2008 financial crash, rising from 34.8 percent in 1999 to 59.4 percent in 2012. Moreover, the socioeconomic gap between Detroit and its surrounding suburbs had only grown wider and remained highly racialized. In 2016, the gap in average life expectancies between Detroit and its surrounding suburbs was over ten years. ${ }^{58}$

\footnotetext{
${ }^{55}$ Charles Lee, ed., Proceedings of the First National People of Color Environmental Leadership Summit (New York, 1992); Peña, Terror of the Machine, 303-05.

${ }^{56}$ Interview with Donele Wilkins, July 14, 2015. On Detroit residents at the conference, see the list of delegates and participants in Lee, ed., Proceedings of the First National People of Color Environmental Leadership Summit, xiv, 215-22.

${ }^{57}$ In his landmark book Dumping in Dixie: Race, Class, and Environmental Quality, Robert D. Bullard noted that "[o]ther environmental groups that have appealed to black community residents grew out of coalitions between environmentalists (mainstream and grassroots), social justice advocates, and organized labor." However, those coalitions were peripheral to the book's narrative, in part because it focused on regions with low union density. See Bullard, Dumping in Dixie, 13.

${ }^{58}$ Data Driven Detroit and the Skillman Foundation, “The State of the Detroit Child 2012," 8, http://www.skillman.org/content/download/2702/24140/file/2012_Detroit_Child_report.pdf (accessed Oct. 19, 2017); Vince Veneziani, "Detroit's Unemployment Rate Nears 50\%," Business Insider, Dec. 16, 2009, http://www.businessinsider. com/almost-half-of-detroits-workers-are-unemployed-2009-12 (accessed Oct. 19, 2017); Christine MacDonald and Charles A. Ramirez, "Life Span for Detroit's Poor among Shortest in Nation," Detroit News, June 3, 2016, http:/www.detroitnews.com/story/news/local/detroit-city/2016/06/02/life-span-detroits-poor-among-shortest-nation/ 85325864/ (accessed Oct. 19, 2017).
} 
Toxic contamination also remained a pervasive problem. In 2000, the EPA estimated that the city had 45,000 contaminated brownfield sites; other estimates reached as high as 90,000. Airborne lead dust from abandoned factories and waste dumps, along with lead paint in vacant homes, contributed to elevated blood lead levels in many children. A 2014 study by the Michigan Department of Health found that 8.2 percent of Detroit children had lead poisoning, and in some zip codes the total was over 13 percent. Despite this ongoing crisis, the city eliminated its lead abatement program in 2012 as part of a larger privatization of the Detroit Health Department. In large part because of emissions from power plants, incinerators, refineries, and diesel trucks and buses, the city also had the highest asthma rate of the nation's eighteen largest cities. $^{59}$

By 2007, only 23,000 manufacturing jobs remained in the city of Detroit. Factories in suburban Wayne County still employed an estimated 60,000 workers, but they were increasingly automated, and regional manufacturing employment had plummeted 37.3 percent since $2000 .^{60}$ The UAW, which had lost over 1 million members since 1979, was still headquartered in Detroit but primarily represented workers in other counties and states. Inevitably, the UAW played a far less prominent role in Detroit politics than in the 1970s. While continuing to challenge unsafe factory conditions, the UAW had also increasingly sided with Detroit automakers on broader environmental questions.

Yet some local unions did remain actively involved in the environmental justice movement in Detroit. In 2009, for example, members of AFSCME Local 207 joined the Michigan Welfare Rights Organization, the East Michigan Environmental Action Council, and other environmental organizations to form the People's Water Board. Between 2012 and 2015, the Detroit Water and Sewerage Department ordered 71,436 water service shut-offs, depriving over 100,000 residents (over one-third of them children) of running water in their homes. The vast majority were lowincome African Americans, many behind as little as $\$ 150$ on their water bills. The People's Water Board, with help from its labor allies (including AFSCME and the Michigan Nurses Association), led a local movement demanding a moratorium on water shut-offs and more affordable utility rates. Their tactics included civil disobedience to block private contractors from carrying out water shut-offs, filing lawsuits, and establishing free "water stations" across the city. Although the United Nations Human Rights Council condemned Detroit's mass water shut-offs in 2014, citing their disproportionate impact on African Americans, the policies continued. ${ }^{61}$

\footnotetext{
${ }^{59}$ Interview with Donele Wilkins, July 14, 2015; Sierra Club, “The State of Detroit's Environment: An Initial Assessment Using the Framework of Environmental Justice” (2012), 1-9, http://www.crainsdetroit.com/sites/ default/files/assets/2946531/State_of_Detroit_s_Environment.pdf (accessed Oct. 19, 2017); Michigan Department of Health Services Childhood Lead Poisoning Program, "2014 Data Report on Childhood Lead Testing and Elevated Levels: Michigan,” Mar. 14, 2016, 1-39, https:/www.michigan.gov/documents/mdhhs/2014_Child_Lead_ Testing_and_Elevated_Levels_Report_515233_7.pdf (accessed Oct. 19, 2017); Keith Matheny, "Kids in Danger as Lead Programs Cut: Detroit's Budget Crisis Slices Aid for Residents,” Detroit Free Press, Apr. 28, 2013, 1A, 11A; Amy Haimerl, "Institute for Population Health, Acting Detroit Health Department, to Lay Off 135 Workers," Crain's Detroit Business, Sept. 22, 2014, http://www.crainsdetroit.com/article/20140922/NEWS/140929973/institute-for-population-health-acting-detroit-health-department-to (accessed Oct. 19, 2017); Zoë Shlanger, "Choking to Death in Detroit: Flint Isn't Michigan's Only Disaster,” Newsweek, Mar. 30, 2016, http://www.newsweek.com/ 2016/04/08/michigan-air-pollution-poison-southwest-detroit-441914.html (accessed Oct. 19, 2017); Michigan League for Public Policy, "Poverty-Children Ages 0-17-SAIPE: Detroit, Michigan," http://datacenter.kidscount. org/data/tables/1692-poverty—children-ages-0-17—saipe?loc=24\&loct=3\#detailed/3/58/false/869,36,868,867,133/ any/3591,13134 (accessed Oct. 19, 2017).

${ }^{60}$ John F. McDonald, Postwar Urban America: Demography, Economics, and Social Policies (New York, 2015), 307.

${ }^{61}$ We the People of Detroit Community Research Collective, Mapping the Water Crisis: The Dismantling of African American Neighborhoods in Detroit: Volume One (Detroit, 2016), 1-22; "In Detroit, City-Backed Water Shut-offs 'Contrary to Human Rights,' Say UN experts," UN News Service, Oct. 20, 2014, http://www.un.org/ apps/news/story.asp?NewsID=49127\#.VakLQvlViko (accessed Oct. 19, 2017); Rose Hackman, "What Happens When Detroit Shuts Off the Water of 100,000 People," The Atlantic, July 17, 2014, https://www.theatlantic.com/
} 
During the same period, the increasingly popular concept of "green jobs" revived some of the debates about environmental policy, labor, and urban revitalization that first emerged in the 1970s. During the Obama administration's first term, nonprofits such as DWEJ and the Green Door Initiative (founded by Donele Wilkins in 2010) received small grants from the EPA and local foundations for green jobs training programs. According to Donele Wilkins, the Green Door Initiative targeted "African American men, primarily between the ages of 22 and 35," about one-third of whom were formerly incarcerated. The trainees obtained valuable skills in lead abatement, asbestos removal, deconstruction, weatherization, and the operation of wastewater treatment plants. Wilkins estimated that they had a 92 percent job placement rate, and made on average "like 18 bucks an hour." However, federal "green jobs" funding focused on training programs, rather than direct job creation in the public sector. It was far more modest than CETA in the 1970s, let alone the Works Progress Administration in the 1930s, which created over 100,000 jobs in Detroit. ${ }^{62}$

While many observers celebrate the "self-reliance" of Detroit community organizations engaged in urban agriculture, such accounts can obscure the importance of federal nutrition assistance and income support programs. Cuts in those programs have increased food insecurity and child malnutrition in Detroit, as in other communities. ${ }^{63}$ The realities of entrenched poverty, brownfield site contamination, and decaying water and sewage infrastructure clearly indicate the need for large-scale public investments and social welfare policies. In addition to cleaning up the urban environment, a renewed federal commitment to full employment and social welfare could reduce the poverty that leaves low-income urban residents unable to afford even a necessity as basic as running water. In this respect, the forgotten debates surrounding Black Lake and City Care are relevant, not only for historians and social scientists, but also for contemporary policymakers and environmental justice activists.

\section{Conclusion}

Between the mid-1970s and mid-1980s, activists working at the intersection of the labor, civil rights, and environmental movements popularized the concept of "environmental justice" for the first time in the United States. While protesters in Warren County referred to "environmental civil rights," the concept of "environmental racism" only became commonplace after the publication of the United Church of Christ's 1987 report Toxic Wastes and Race in the United States. In the years between that report's publication and the 1991 First People of Color Environmental Leadership Summit, scholars and activists began to refer to an "environmental justice movement." Increasingly, campaigns against disproportionate pollution in lowincome communities of color became synonymous with "environmental justice." In important respects, however, the new environmental justice discourse neglected earlier themes. In the decade before the Toxic Wastes and Race report, participants in the Black Lake and City Care conferences, and in the UEC, recognized that people of color, and working people in general, were not only the disproportionate victims of pollution, but they were also structurally dependent on the industries that poisoned their communities. Efforts to clean up the environment, activists in

business/archive/2014/07/what-happens-when-detroit-shuts-off-the-water-of-100000-people/374548/ (accessed Oct. 19, 2017); Interview with Roger Colton, July 27, 2016; Rector, “Accumulating Risk," 295-317, 341-58.

${ }^{62}$ Interview with Donele Wilkins, July 14, 2015; Michelle Chen, "Where Have All the Green Jobs Gone?" The Nation, Apr. 22, 2014, https:/www.thenation.com/article/where-have-all-green-jobs-gone/ (accessed Oct. 19, 2017); Elizabeth Clemens, The Works Progress Administration in Detroit (Chicago, 2008), 7.

${ }^{63}$ Kami Pothukuchi, "Proposed Cuts in Food Stamps Will Hurt Detroiters," Michigan Citizen, Oct. 6, 2013, A10; Jonathan Oosting, "Food Stamp Cuts Coming to Michigan, 1 of 4 States Not Taking Action to Avoid Them," MLive.com, Sept. 24, 2014, http://www.mlive.com/lansing-news/index.ssf/2014/09/food_stamp_cuts_coming_in_ mich.html (accessed Oct. 19, 2017). 
the UEC and other groups recognized, could attract a broad constituency only if they offered concrete solutions to that structural dependence.

The fact that labor-environmental-civil rights coalitions largely collapsed at the national level in the 1980s did not prove that these movements were inherently incompatible. The socialdemocratic policies advocated in the Freedom Budget, and which were central to the Black Lake conference, could have facilitated broader and deeper labor-civil rights-environmental coalitions. Auto workers or inner city residents with secure livelihoods had more freedom to challenge polluting industries than those standing in unemployment lines. Conversely, the federal government's abandonment of full employment and embrace of austerity made coalitions between social movements exceptionally difficult. Nevertheless, the persistence of such coalitions in the 1980s, from the Gulf Coast to Silicon Valley, offers a glimpse of what might have been (and what still could be), given a different political and economic context.

The environmental justice movement continued to spread in the 1990s and 2000s, despite the erosion of the institutions that once facilitated its emergence. In the past two decades, some segments of organized labor have accepted the "jobs versus the environment" framework offered by the fossil fuel industry and, most recently, the Trump administration. Others, like the Just Transition Coalition and the Climate Justice Alliance, have connected labor with the environmental justice movement. ${ }^{64}$ The history of such alliances, from Black Lake to the present, confounds characterizations of environmentalism as "post-economic"-opposed to the interest of workers, primarily localist and defensive, and unconcerned with redistribution. It demonstrates that social movement coalitions can persist, and sometimes succeed, despite the efforts of political opponents to divide them.

Josiah Rector is the Hulings Assistant Professor of U.S. and Environmental History and Culture at Northland College in Ashland, Wisconsin. He received his Ph.D. in History from Wayne State University in 2016. His dissertation, "Accumulating Risk: Environmental Justice and the History of Capitalism in Detroit, 1880-2015," won the Urban History Association's Michael Katz Award for Best Dissertation in Urban History. His research focuses on African American history, urban history, labor history, and the history of the environmental justice movement.

\footnotetext{
${ }^{64}$ Sekou Franklin, "Race, Class and Green Jobs in Low-Income Communities in the US: Challenges for Community Development," in Class, Inequality and Community Development, eds. Mae Shaw and Marjorie Mayo (Bristol, UK, 2017), 77-92; "Navajo Tribal Members Demand Just Transition to a Sustainable Economy," Indigenous Environmental Network, Apr. 14, 2016, http://www.ienearth.org/peabodys-declaration-of-bankruptcy-is-no-surprise/ (accessed Oct. 19, 2017).
} 